\title{
The Analysis of College Political Education and Humanities Quality Education Resources in Olympic Movement
}

\author{
Chen Lihe ${ }^{1}$, Yu Xiaogang ${ }^{2}$ \\ ${ }^{1}$ College of Humanities and Social Sciences, Jingdezhen Ceramic Institute, Jiangxi, Jingdezhen \\ Jiangxi, 333403 \\ ${ }^{2}$ College of Humanities and Social Sciences, Jingdezhen Ceramic Institute, Jiangxi, Jingdezhen \\ Jiangxi, 333403
}

Keywords: Olympic system; College students; Education; Humanities

\begin{abstract}
Olympic system contains rich ideological and cultural quality education resources. These provide the enlightenment for enriching the content of university education and humanities quality education, and broaden education teaching idea. These education resources are mainly manifested in six aspects: patriotism and national spirit, participation, dare to competition, advocating equality, unity and strive, which coincides with Chinese colleges and universities education which advocate quality education concept, and some content of socialist core values advocate. The Olympic movement advocates harmonious and comprehensive development and adapts to the development of today's college students. Olympic education and practice are the effective ways to realize education and humanities quality education goals and promote college students' harmonious and comprehensive development.
\end{abstract}

The Olympic Games can be said to be one of the world's most influential social activities. It has a larger role in promoting political, economic and social development of the host country, and the social comprehensive benefit is very large. Olympic Games is the main and important part of international Olympic movement, people are watching the host country's economic and political influence Olympic Games brought, in fact, the Olympic movement has a very important role which often is ignored, the effect on people's education. China held a session Olympic Games of the only one in 2008, the impact of its influence is in every aspect of our society. Two years before the Olympic Games to finish, Beijing Olympic Games held various activities, one of which is known as "Beijing Olympic school action education plan" activity. It should not be forgotten. Education workers cannot ignore the importance of the activity, though this activity lacks wider attention and follow-up activities. There is no other city schools followed suit, but its meaning is very important. It told people that the system is not just a sport; it has a very important role in education for teenagers. Due to too much success of Beijing Olympic Games, most people did not pay attention to the significance of the activity, which shows that all walks of life in our country, including education function and the value of Olympic movement have not gain enough understanding and hard to reach a consensus.

In our country, although there are some predecessors and scholars such as Xu Yinsheng who had conducted studies of Olympic education, and have individual regions try, but didn't continue or formation system. There are less people who understand the relationship between Olympic movement and education in our country, and the use is relatively more mature in western developed countries. In fact, many of the Olympic movement are high quality education resource. Whether physical education workers or education and quality education workers should fully understand and know the education of Olympic movement and function and value of humanity quality education, and use these to influence our country's university students. Make college students feel the passion of Olympic movement, the feeling of patriotism and national pride and sports shows struggle, respect, cooperation, fearless and happy mental quality, and benefit from their own thoughts and behavior. College students are the core of social development of our country power, and are very active in social structure of molecules. College students are sensitive to new things and social hot 
spot. The year 2016 is another Olympic Games year. "Dilettante watches the scene of bustle, adept guard the entrance". As workers in college of physical education, political education and quality education, we should not only let the students watch the scene of bustle, and should make full use of the education value of the Olympic movement and timely carry out the relevant education and practical work by using the influence in the world's largest social activities to improve their patriotic spirit and national spirit, enrich their cultural quality, improve the moral quality, have different education experience and social sense of responsibility, experience sports promoting universal values, and improve the comprehensive qualities of college students.

\section{Education is an important part of the Olympic movement}

Olympic education committee is one of the important compositions of the Olympic Games system. Chinese Olympic movement pioneer He Zhenliang had served as chairman of the committee and carried out a series of effective work. Pierre DE Coubertin, founder of the revival of modern Olympic movement, thought the original purpose of the Olympic movement was to revive France's school education [1], to change the backward education ideas and old France at that time and the old way of teaching. We can say that education is the purpose of modern Olympic movement Coubertin Renaissance and the original desire. Pierre DE Coubertin loved sports as a child, and was also close to personally take part in many sports, and know well of the ancient Olympic sports, education and political functions of the Olympic Games, the virtues of ancient Olympic system, hope to learn from the ancient Olympic movement pattern for education of young people to revive the national education system, change the heavy knowledge education and mechanical system of education. In order to achieve the ideal education reform and revitalization, Coubertin combined education reform and the revival of the Olympic movement, and established the new system. Although is frustrated, unwieldy, he finally achieved the original dream. Because of the Olympic movement has a profound understanding, Coubertin combined sports education function and value, which is related in some occasions and works, such as "sports get onto the world stage in Greece with KeGe and, as appears in education under the guidance, it rises again in the early 19th century. The Athenians found sports the most beautiful and the best way of education. It can prompt the balanced development of human body; make the balance of body and mind, make people feel happily and more beautiful life" . [2] Physical education function is not a substitute for other disciplines, and it is to promote physical, psychological, will quality, and the best way of all-round development of personality.

Olympic education is the important content of modern Olympic system. Olympic Charter expounds the Olympic education many times, such as: "Olympic spirit is to combine various qualities of the equilibrium, body, mind and spirit, and a philosophy of life to improve it. It fuses sport with culture and education." [3] Olympic tenet is "educate youth Olympic spirit without any form of discrimination through mutual understanding, friendship, unity and fair competition spirit in sports activities, to build a peaceful and better world." [3] Juan Antonio Samaranch also wrote: "left education, Olympism has lost its meaning". It is visible that the origin of modern Olympic movement is associated with development and education relations, takes changing education pattern and raising the overall quality of young people as the prerequisite, and is the same view as advocating humanistic quality education in our country and all-round development education idea.

\section{Positive energy shown in Olympic movement can be used as the main content of education and humanities quality education}

Over the years, our country's education and humanities quality education played a good role in talents cultivation, but with the development of the society, college education and humanities quality education must be kept updated and progress in content, means and form to meet the modern ideology and ideas of young people. Because Olympic Games is the attention of young people, and college students like watching sporting events, which provides the basis and premise for getting Olympic movement into education and humanistic quality education. The positive energy 
cases happened in Olympic movement have education value, and are the feasible content as college education and humanities quality education content, such as patriotism and national spirit, unity, friendship, participation spirit (in a harvest), respect, struggle, struggle, and beyond, competition, fairness, impartiality, punishment, success and failure, gain and loss, dedication, passion and joy, and volunteer activities, etc. reflected in the process of game. These are not only the embodiment of Olympic spirit, they are also the education goal ideological education and the humanistic quality education to achieve, at the same time it also consists with our country socialist core values, such as harmony, equality, justice, rule of law, values, patriotism, honesty, friendly.

Olympic movement fuses healthy spirit quality into a healthy body. Olympic movement education and humanities quality education resources are mainly reflected in six aspects, namely, patriotism and national spirit, participation, dare to competition, advocating equality, unity and friendship and strive.

A. Patriotism and national spirit in Olympic movement are the most vivid ideological education contents.

The cultivation of patriotism and national spirit is an important content and the main body of education in colleges and universities. It has different forms in every country, and is the fundamental of the national education. Under the background of market economy, from the current form of the development of the society and college students with active thinking, simple moralistic patriotism and national spirit cultivation are of less effect obviously, and fresh cases and stories, force of example can effectively promote the formation of college students' patriotism and national spirit. Let the student view, understand, or participate in the national or important matters to experience patriotism and national spirit, through their influence shown on the world stage to improve patriotism and national pride. Our country constant breaststroke sports events in the world could produce such effect, including the Olympic Games. When your country's athletes are in the game, whether inside or outside, you cheer and applause for them; When their favorite athletes win the championship and run with flag full-court; When you see your country's flag rising on the world arena with national anthem singing; These will make people feel heartfelt pride and sense of national pride as a Chinese, and with the same feeling of honor. The feeling is real, memorable, and can lead to feelings, thought and behavior change. From this point of view, many of the Olympic movement links can consciously as university student patriotism education content to promote the national spirit.

B. Participating spirit is the foundation in all activities, and is the beginning of success

Coubertin has an axiom, namely: "Olympic Games importance is not the victory, but participation; the essence of life is not claim, but the struggle; what matters is not the final conquest, but how to go to struggle process." [4] The literal translation for it is "the important thing is process, rather than the result". It is to remind the world that wanting to succeed must be involved, and the process of success is the most profound. Indeed, participation is the beginning of success. If you always stay in the plan and oral is impossible to have success. To participate in sports is the basic requirement, and encourage and mobilize people to join the slogan of sports and enjoy sports, because no matter how sports level is, we can only have experience. First of all, participate in to sense its fun, to know their own deficiency and strengths, and to perceive the success and failure. By promoting the participation of Olympic sports spirit and consciousness, we can prompt students to be bold, dare to try new, reform and innovation, dare to break through their own ability and cognitive limitations, improve innovation spirit and practice ability, even if not succeed, but if paid, and enjoyed the process, it is another kind of life wealth and has laid the groundwork for your next success.

C. Dare to competition is the essence of the Olympic spirit

Competition, surpass, innovation are always concomitant changes and the development of human society, the development of all successful people relate to dare to competition, fearless setbacks, overcome difficulties and constantly improve themselves. Influenced by many factors, such as family environment, education system, our country college students, compared with the western developed countries, are lack of the spirit of competition. It is the shortcoming of talents 
cultivation in our country, and is not conducive to the formation of an innovative society. Sports are advocating competition, also is in the middle of competition to improve themselves and achieve their goals, often contact and participation in sports are to change weakness, and cultivate courage, improve competition consciousness and the spirit of the best "cure". It has formed a consensus in many countries. Due to the Olympic movement advocates competition, rewards "swifter, higher, stronger" social activities, refine the content of the spirit of competition, and transmit to the college students, as humanity quality education content can effectively inspire the students' competitive consciousness and strengthen the spirit of competition.

D. Advocating fair and equal

Fair play is the lubricant of social development. Sports competition is fair and impartial, and it specified all the behavior of Olympic competition, which is the essence of the Olympic spirit. Its emphasis is that superior by principles of justice has the respect and affection of the world, and all the competition behaviors lack of ethics will be blamed and punished. Sports competition is abide by the rules, aboveboard competition, is the model of human society competition. Put this element penetration into the ideological education of college students can effectively improve the competitive consciousness of fairness and justice, and form a fair and just competition behavior, make the fair and just competition as the behavior norms and values of college students. It has a long term effect on college students becoming qualified social talents in the future, and the benign development of the whole society.

E. The basic purpose of the Olympic movement is to strengthen solidarity and friendship.

The modern Olympic Games is hoping all kinds of communication in the form of sports games, gets together the peoples of the world, deepens understanding and friendship between each other, and then promotes unity, peace and progress in the world. Emphasizing the principle of college students has the positive significance in forming a good interpersonal relationship and team spirit. College students through personal participation sports can understand and learn to respect the referee, respect opponents, respect them, or will be affected "punishment". This is a very good experience education. Through the participation, all kinds of sports, college students can know how to communicate with others and get along, know how to unite, help others or from others for their help in understanding the value of friendship and the importance of the team, and improve on the thought and behavior which is unmatched by any textbook and simple sermon. Learned to get along with others, and then promote the understanding of themselves or others understanding to further form the tolerant spirit.

F. Tenacious struggle and progress is the soul of Olympic spirit.

Struggle and fighting spirit is the most blessed and great human spirit, which also is the innovation human society to progress, the courage to reform and to encourage society to get prosperity and development. To encourage and reward struggle is the soul of the Olympic spirit. Olympic movement advocates "swifter, higher, stronger", which is to call for people to strive, never give up, constantly climb the peak of life. The Olympic spirit is to want people to have perseverance, indomitable effort, and enterprising spirit, encourage people to dare to struggle with difficulties, not afraid of setbacks, do not bow, where to fall and where to climb up. These qualities are what college quality education need, also is what the contemporary college students are relatively lack of. Sports are very good "supplements". The characteristics of sports determine that people engaged in sports must dare to challenge and be aggressive; otherwise it will lag behind the others and leads to failure. Therefore, through various channels and forms, college students contact and understand the spirit of the Olympics essence. It can subtly promote their perseverance and fighting spirit cultivation and self-consciousness.

\section{The values of Olympic movement can promote college students' harmonious and comprehensive development}

The Olympic movement is to advocate people dare to challenge, scaling new heights, and is a reminder to the harmonious development of body and mind at the same time to form the correct outlook on life. If the Olympism is a philosophy of life, "harmonious and comprehensive 
development" is the basic idea of this kind of life philosophy and way of life because adolescents have a positive guidance function. While "harmonious and comprehensive development" is the education idea always advocated in our country modern education, therefore, the Olympic movement can provide rich nutrients in order to achieve this kind of education idea and soil.

A. Ancient and modern Olympic movement provide beneficial enlightenment for college students' harmonious and comprehensive development

The ancient Olympic sports' harmonious and comprehensive development thought can be summarized as follows: one is the pursuit of the harmonious development of body and mind. Pursued by the ancient Greeks "perfect image", it is the pursuit of body and mind, hoping that through sports bodybuilding, noble develops towards a more "complete human development". This is persistent pursuit and yearning to person's body and soul harmony, and had to maintain social stability and prosperity in ancient Greece, which also has created more than one thousand years glorious ancient Olympic Games and macro thick history and culture. It laid a foundation for the pursuit of the harmonious and comprehensive development of human society and for posterity the humanistic spirit, humanistic care. The second is the pursuit of harmonious and comprehensive development of education. Ancient Athenians have long put forward the concept of education, all-round development of body and mind and the Spartans only pursue strong body and military ability. From the point of modern concept of education, the education concept of Athens is conform to the trend of social development, which is the ancient Athens education and culture of the important influence on later generations. The Athenians have long realized that sports can not only enhance physical fitness, but also temper and sublimation of moral and spiritual quality, which can reach "perfect". They are the first people put forward the comprehensive development of body and mind in human history. The ancient Greeks aesthetic idea core and goal are to pursue a complete and unified, perfect and harmonious development of men and harmonious development of society as a whole as the supreme ideal, which can be seen everywhere in humanities thought system of ancient Olympic Games.

The harmony of ancient Olympic sports concept and the idea of all-round development is developed and extended by modern Olympic movement. "Olympic charter" made the following regulations: "the Olympic tenet is to make the sport the harmonious development service so as to promote to build a peaceful society and maintain the dignity of the people." [3] Promoting the harmonious and comprehensive development of the Olympic movement's ideas and values conforms to the development trend of modern society, and meets the needs of the development of modern talent, also meets the needs of the development of a harmonious society in our country. Revered concept and modern education idea are consistent. The advocate and promotion of fair, abiding by the rules can provide ideological basis for forming good campus order and legal environment for colleges and universities. The show of unity, friendship, help, respect, etc. can also be a vivid example and a good example for the harmonious coexistence of college groups and classes. Its famed spirit and the spirit of fair competition, the courage to strive for healthy development provide the inexhaustible spiritual power for college students and the healthy growth of the individual.

B. Olympic education and practice are political education and quality education goals, and effective ways to promote college students' harmonious and comprehensive development

The Olympic education, as the important content of the Olympic movement, has the characteristics of strong practicality, and can be carried out through various kinds of sports activities and events, conducting Olympic knowledge lectures to carry out the specific ways and methods such as Olympic education course. After hundred year' s development of modern Olympic movement practice, it has been proved that the Olympic spirit is one of the power sources to better realize the development of human society, which has the very good education significance and guiding significance for realistic society. It advocates understanding each other, unity, help, friendship, respecting the opponent, which promotes college students communication and exchanges between different groups, improves and corrects students' selfish, autistic, self-centered bad thoughts and behavior. Especially in sports practice, participation spirit, cooperation spirit, and 
help others, respecting the opponent and obeying the rules of conduct and spiritual essence are blended in among them, which can effectively contribute to the formation of college students' good conduct and specification, and ultimately form a healthy and active lifestyle. "Olympic charter" points out: "Olympic creed lifestyle is being built in to the joy of effort, the education value of good example and based on fundamental of general ethical principles." [3] By promoting the Olympic spirit, participation in Olympic movement practice, learning and spread of excellent athletes' role models can produce subtle effects on the growth of college students. In sports, it can make college students unconsciously conform to Olympic spirit values and norms, and translate into their own code of conduct and value standard. The formation of college students' good behavior and way of life has a positive meaning and function to prevent and avoid college students' bad habits and behavior like Internet addiction, lack of independence and selfishness, fighting and so on.

\section{Conclusion}

The Olympic system has very good values and education idea, which is gradually known by people and mining, but did not play its proper role. The preached and spread of spirit and culture have been far beyond the sports itself. It advocates a perfect and harmonious philosophy about man's all-round development and value standard, and shows to the world view of an ideal way of life and thought. The pursuit of education thought is supreme, and the system has rich ideological education and humanities quality education resources. With the integration of university education, it will help to improve the humanity quality education system in colleges and universities to enrich the content of education and humanities quality education, and to improve the quality of education in colleges and universities, and it plays a positive role in training high-quality and comprehensive development of health talents for the society.

\section{Acknowledgements}

Fund project: Jiangxi province social science planning project in 2012 (No. : 12TY10)

Author introduction: Chen Lihe (1972 -), male, Han ethnic group, Jiangxi Jinxi, professor, tutor, research direction: sports education theory and practice, sports, art and aesthetics.

\section{Reference}

[1] Xiong Douyin. Theory of Olympic education [J]. Journal of Jilin Institute of Sport, 2005, 21 (1) : $1-4$.

[2] Ye Wuwei. Olympic education new theory [J]. Journal of Xi 'an Sports Institute, 2006, 23 (2) : 44-47.

[3] Wang Donghong. The Olympic spirit and harmonious society [J]. Journal of Theory, 2007.8

[4] Tian Hui, et al. Near to the Olympic [M] Beijing Sports University press, 2007

[5] Ru Xiu. International understanding education research in Beijing Olympic education "knot" communication activities [J]. Journal of Capital Institute of Physical Education, 2011, 5

[6] Fang Qianhua. The empirical study of modern Olympics and interactive development of higher education---based on the investigation and revelations of universities in Beijing participating in the Olympic Games [J]. Journal of Sports Science, 2010, 2

[7] Pan Xia. Olympic education promoting thinking [J]. Journal of Sport Culture Tribune, 2012.7

[8] Ru XiuYing. Beijing Olympic education heritage research of primary and secondary schools [J]. Journal of Xi 'an Sports Institute, 2012.1

[9] Xiong Xiaozheng. Olympic education and adolescent personality [J]. Journal of Sport, 2008.1 